$$
\begin{aligned}
& S H \\
& 370 \\
& \text {. M48 }
\end{aligned}
$$




\section{Hollinger Corp.} pH 8.5 


\section{THE OCCURRENCE IN VIRGINIA OF GREEN-GILLED OYSTERS SIMILAR TO THOSE OF MARENNES}

By Philip H. Mitchell and Raymond L. Barney

From BULLETIN OF THE BUREAU OF FISHERIES, Volume XXXV, 1915-16

Document No. $850 \quad: \quad: \quad: \quad: \quad: \quad: \quad: \quad: \quad: \quad: \quad:$ Issued August 11, I9I7

PRICE, 5 CENTS

Sold only by the Superintendent of Documents, Government Printing Office, Washington, D. C.

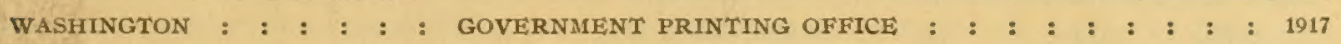


D. of D.

SEP $\quad 27 \quad 1917$ 


\title{
THE OCCURRENCE IN VIRGINIA OF GREEN-GILLED OYSTERS SIMILAR TO THOSE OF MARENNES.
}

\author{
By PHILIP H. MITCHELL, and RAYMOND L. BARNEY.
}

\begin{abstract}
$*$
Contribution from the United States Fisheries Biological Station, Woods Hole, Mass, and the Biological Laboratory of Brown University.

\section{INTRODUCTION.}

The appearance of green-gilled oysters in Lynnhaven Bay, Va., in such large quantities during the fall and early winter of 1915 that several of the oystermen of the vicinity were unable to sell their product because of the dark-colored gills led to this investigation. The problem is of considerable economic interest since the entire oyster industry of Chesapeake Bay was at stake, the green-gilled oysters being found in locations many miles distant from one another. Moreover, if this outbreak could be proved to be an exact reproduction of the greening of the popular Marennes oysters, it might be the basis of oyster culture in Virginia from an entirely new point of view. Further than this, the study offered an interesting scientific problem which narrowed itself down, in the consideration of the writers, to a physiological and chemical study of the pigment and the manner in which the oyster re-acted to it. The main purpose, however, in this study has been to find whether or not the greening of the gills in the Lynnhaven oysters is the same as that in the choice Marennes oysters, for a glance at our American oysters shows that they are very similar in general appearance and in the distribution of the pigment to the descriptions and drawings of the Marennes oysters.

\section{HISTORY.}

In the past there has been considerable work done on the green coloration of oysters, especially in Europe. Papers have been written on both the green-gilled and the copper-green oysters.

The genuine green-gilled oyster was first worked on by M. Gaillon, who published his first paper in 1820 . In this paper he explained the French custom of placing the oysters in claires or large reservoirs just within the high-tide mark and allowing them to remain there for a considerable length of time or until the gills and palps showed the green tint. He recognized that if the tanks contained a certain diatom, Navicula ostrearia, in large quantities, the oysters would take on the green coloration, but that when the oysters were taken from the tanks and placed in fresh sea water, or allowed 
to remain in the tanks after the growth of the diatoms had ceased, the oysters would arrive gradually at their normal color in three or four weeks. Furthermore, Gaillon pointed out that common chlorophyll was not the coloring matter. His conclusion that the Navicula ostrearia was the cause of the greening of Marennes oysters was accepted and corroborated by other European biologists later in the century. Gaillon, however, offered no proof as to how the green substance reached the gills. He noticed that no other organs of the body except the gills and palps were ever colored, but he did not try to show how the coloration took place. He intimated that perhaps the green substance entered the gills through the gill filaments, but he could not offer scientific evidence of such entrance.

Valenciennes in 1841 drew attention to the fact that beside the gills and palps, the liver and intestines often showed a green tint, while the heart, reproductive system, muscles, and blood showed no abnormal color whatsoever.

Gaillon, in a second paper in I 824, suggested what appeared to be the proper explanation of the green colorations in the gills, palps, liver, and intestines by saying that the coloring material is taken into the alimentary canal and that the oyster's gill tissue selects and deposits the coloring matter much the same as the osseous tissue of pigs fed on madder selects and deposits the red coloring of that plant. Thus it will be seen that Valenciennes in $\mathrm{r} 84 \mathrm{I}$ was hardly more than corroborating the work done by Gaillon in I 821 and I824. Valenciennes, however, did considerable work on the chemistry of the pigment. He found that the coloring material of green-gilled oysters was insoluble in water, alcohol, ether, weak alkalies, or weak acids and that the only reagents that would dissolve the pigment were those that destroyed it forthwith. He, furthermore, came to the conclusion that the green-gilled pigment had no connection whatsoever with any metallic element, thus putting the green-gilled problem in a different category from the copper-green oyster with which it had oftentimes been confounded.

In I 86I Coste brought forth the suggestion that the greening of Marennes oysters was due to iron salts in the soil on the bottoms of the claires. This theory had been advanced several times, but Bornet and Ad. Chatin showed without much doubt that in certain places the oysters in the claires would remain indefinitely white and then, suddenly, would take on the green coloration, due in their estimation to a change in the flora of the park and not because of the fact that the floor of the claire had changed in its elemental composition. Sullivan in 1870 came to the conclusion that green-gilled oysters contained no copper. Dyer in 1877 showed that oysters put in dishes that contained Navicula ostrearia became green in 36 hours. Puysegur in 1880 published the results of some of his observations on greengills, mentioning especially that he had turned the gills of normal oysters green by immersing the oysters for only a few hours in water that contained the Navicula. Borney, Ducaisne, and others observed the same results from similar experiments.

In 1886 Ray Lankester, the eminent English biologist, affirmed the work of Valenciennes as regards the absence of any metallic compound in the green pigment that caused the gill coloration. In this paper Lankester made it his purpose to demonstrate three things:

I. That the oysters do swallow the Navicula ostrearia.

2. That a pigment having the same peculiarities determined by Valenciennes, or from which Valenciennes's pigment could be derived, actually occurs in the Navicula ostrearia. 
3. That there is some mechanism in the oyster by which the pigment of the Navicula ostrearia, being taken into the oyster's alimentary canal, can be absorbed and deposited in the gills and palps.

These points Lankester well brought out. He concluded, through the fact that he found many frustules of the diatoms in the intestines and stomachs of green-gilled oysters, that they must have swallowed them. Further than that, he observed the pigment of the Navicula ostrearia chemically and spectroscopically and found it to have exactly the same properties as the green pigment of the Marennes oyster. Lankester also did considerable work on the histology of the oyster gill in an effort to find and demonstrate the exact distribution of the pigment. This distribution of green material he found to be in amoboid leucocytes that work their way through the epithelial cells of the gills and move around on the external surface of the gills. These cells he called "secretion cells," and they are found on all normal oyster gills. With this work Lankester also published a minute description and a set of colored drawings of the Navicula ostrearia and the distribution of its pigment throughout the oyster.

In I899 Herdman and Boyce, two English investigators, published a paper on "Oysters and Disease," in which they drew attention to the fact that copper-green oysters and green-gilled oysters were two different abnormalities. This paper was merely a review of the work that had been done on the green oysters up to that time, supplemented by a study of the histology of the two different types of green abnormality. Ryder, whose work has been published in several United States Fish Commission reports, did much investigation on green oysters, but the copper-green oyster received his attention especially.

The only papers dealing with the conditions that show the effect environment may have on the growth of the Navicula ostrearia and the consequent greening of the oysters are those by Boubés and Calvet. Boubés, in his "L'ostreiculture à Arcachon," gives a general survey of natural, legal, and economic conditions affecting the oyster industry at Arcachon, contrasting these with circumstances at Marennes. In this publication he mentions the most important fact that, when the claires are allowed to get too salt, the product, the greengill, is not so good. He intimates in this statement that a high specific gravity is not conducive to the life of Navicula ostrearia. Calvet, 1910, in "Du Vertissement des Huitres," discusses the conditions that tend toward an optimum "greening" of oysters left in the claires, taking into consideration the temperature, the specific gravity of the water, the depth of the water, the nature of the bottom, and the effect of light on the growth of the Navicula ostrearia, and therewith the greening of the gills.

\section{THE GREEN-GILLED OYSTERS OF VIRGINIA.}

The oysters found to possess this abnormal condition in Virginia were the large typical Chesapeake oysters. The gills at the height of the epidemic showed a green color, which extended in many cases up into the palps, turning them, also, a greenish color. The liver appeared a somewhat darker brown than in the normal oyster, but the rest of the oyster's body seemed perfectly normal. The larger number of the oysters observed were in a well-nourished condition and appeared very "fat." Indeed, the people in the vicinity of Lynnhaven used them freely, claiming that they possessed a more delicate flavor than the ordinary white oyster. The oyster dealers of the place also shipped considerable quantities to distant destinations where, according to reports, they received ready sale. 
The epidemic itself was spread over large areas, which, in some cases, were many miles distant from one another. Lynnhaven Bay, with the two large creeks that combine to form it, was the seat of the most serious outbreak at the time of this study. The same location had been reported to have suffered in a like manner in rgr2. From testimony taken from various oystermen of Hampton and Phoebus, greengill had appeared at different dates, but all who were interviewed agreed that the last general epidemic occurred in гgг 2. At that time the greengill was distributed the entire length of Hampton Bar and Flats from Newport News to Phoebus and Mill Creek, and both the northwest and southwest branches of Back River also suffered. The present outbreak again affected Mill Creek and both branches of Back River. Farther north and more on the open coast greengill was found in considerable quantity on Drum Island Flats, but Hampton Bar and Flats at the time of this investigation were free of the epidemic. It was learned, however, that oyster beds from Cobbs Island down to Goodwins Island had suffered in various years and at various locations from greengill.

An effort was made in taking these data to get general information from those interviewed in regard to weather conditions, temperature, depth of water, and general locations of outbreaks with their relationship to the greening, but with little success. The theory offered by one individual would be contradicted by the next person interviewed, so that no facts or ideas common to all observers were obtained from those most closely connected with the oyster industry.

Not being able to gain specific knowledge of the general relationships of greengill with weather, temperature, salinity, etc., from interviews, and at the same time trying to find some connection between the true Marennes green-gilled oyster and the greengill at hand, it was decided to take water samples from locations where the epidemic was prevalent and observe the temperature, salinity, and the vegetable life in the water. Samples thus studied were taken on January 4,5 , and 6, I9I6. The weather of these days was rainy or cloudy, with the temperature varying from the freezing point to about $15^{\circ} \mathrm{C}$. The water samples were taken from places where the water was not more than 6 inches deep and which, therefore, was open to a considerable change of temperature during the day and night. No doubt the temperature of the water during the night lowered to within 2 or $3^{\circ} \mathrm{C}$. of freezing, while during the day it increased to perhaps $\mathrm{I} 2$ or $\mathrm{I} 3^{\circ} \mathrm{C}$. For about a week before these samples were collected, there had been a heavy storm blowing from the southeast, and the bottoms of Lynnhaven Bay and the coves, which up to the time of the storm were reported to be covered with a green carpet of vegetable life, showed nothing but the typical gray clayey mud with the water very much roiled. Samples were taken, however, and in five of the six samples obtained in various parts of Lynnhaven Bay diatoms were found that exactly answered the description of the Navicula ostrearia as set forth by Lankester. The temperature of the water ranged from $\mathrm{Io}$ and $\mathrm{II}^{\circ} \mathrm{C}$. in shallow places to 5 and $6^{\circ} \mathrm{C}$. in the deeper water. The specific gravity of the samples varied from r.or 8 to r.org. The results of this collection were as follows:

\begin{tabular}{|c|c|c|c|c|c|c|c|}
\hline Location. & $\begin{array}{l}\text { Tempera- } \\
\text { ture. }\end{array}$ & $\begin{array}{l}\text { Specific } \\
\text { gravity. }\end{array}$ & $\begin{array}{l}\text { Navicula } \\
\text { ostrearia } \\
\text { present. }\end{array}$ & Location. & $\begin{array}{l}\text { Tempera- } \\
\text { ture. }\end{array}$ & $\begin{array}{l}\text { Specific } \\
\text { gravity. }\end{array}$ & $\begin{array}{l}\text { Navicula } \\
\text { ostrearia } \\
\text { present. }\end{array}$ \\
\hline $\begin{array}{l}\text { Opposite Croonenbergh's } \\
\text { oyster house. } \\
\text { Croonenbergh's claire....... } \\
\text { Cove at Willard Diggs..... }\end{array}$ & $\begin{array}{l}{ }^{\circ} \mathrm{C} . \\
\begin{array}{r}11.3 \\
10.0 \\
5.6\end{array}\end{array}$ & $\begin{array}{l}\text { I. Or } 8 \\
\text { I. or } 9 \\
\text { I. or } 8\end{array}$ & $\begin{array}{l}\text { Yes. } \\
\text { Yes. } \\
\text { Yes. }\end{array}$ & $\begin{array}{l}\text { Croonenbergh's cove....... } \\
\text { Opposite Fentress's crab } \\
\text { pound ................ } \\
\text { Fentress's crab pound.... }\end{array}$ & ${ }^{\circ} \mathrm{C}$. & & $\begin{array}{l}\text { Yes. } \\
\text { Yes. } \\
\text { No. }\end{array}$ \\
\hline
\end{tabular}


Other observations on specific gravity and temperature were recorded as follows:

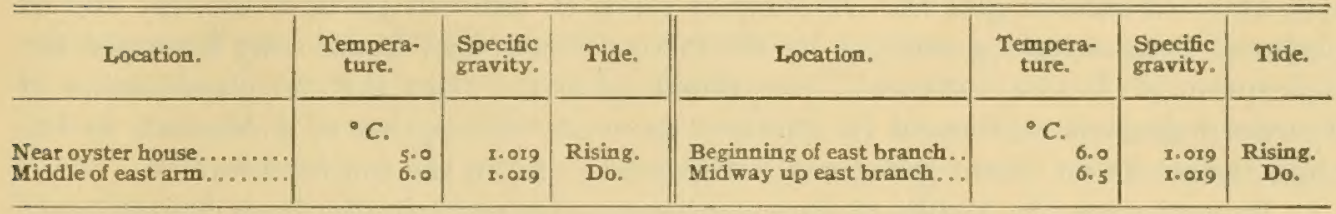

At the same time with these observations, examinations were made of the contents of the stomachs of several oysters just taken from Croonenbergh's Bar, and in every case diatoms or the frustules of diatoms were found that were of exact description of the Navicula ostrearia.

In a similar manner, as at Lynnhaven, the water of Back River was studied. Whereever a water sample was taken, oysters were dredged and in every case showed the greengill. The weather there was the same as had been experienced at Lynnhaven, and the water was very much roiled. The specific gravity and temperature of the water varied from I.OI5 to 1.017 and from 8.5 to $10^{\circ} \mathrm{C}$, respectively. In the five samples taken, approximately half a mile apart, two contained diatoms which were identified as Navicula ostrearia. The observations in Back River were as follows:

\begin{tabular}{|c|c|c|c|c|c|c|c|}
\hline $\begin{array}{l}\text { Creek south of Hampton } \\
\text { Institute Farm ........... } \\
\text { Sherwood Farm. . . ...... } \\
\text { Creek on opposite side.... }\end{array}$ & $\begin{array}{l}1.017 \\
1.016 \\
1.015\end{array}$ & $\begin{array}{l}{ }^{\circ} C . \\
9.0 \\
10.0 \\
9.5\end{array}$ & $\begin{array}{l}\text { No. } \\
\text { Yes. } \\
\text { No. }\end{array}$ & 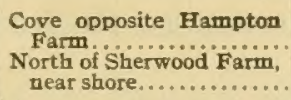 & $\begin{array}{l}\text { I. } 015 \\
\text { I.0165 }\end{array}$ & $\begin{array}{l}{ }^{\circ} \mathrm{C} . \\
9.5 \\
8.5\end{array}$ & $\begin{array}{l}\text { Yes. } \\
\text { No. }\end{array}$ \\
\hline
\end{tabular}

The Navicula ostrearia was also found in the green scum that clung to the shell of one of the oysters dredged in this observation.

On January 19, I916, a sample of water from the western arm of Lynnhaven Bay, Va., was examined after a two days' shipment during very cold weather. The sample, despite the cold weather, yielded many different kinds of vegetable organisms, among which was observed the Navicula ostrearia. On February 18, 1916, a water sample from Lynnhaven Bay was examined that showed by far a larger number of organisms with the characteristic Navicula ostrearia appearance than any water sample yet taken. On March 17 another water sample was received from Lynnhaven and examined, but this showed no Navicula organisms whatsoever. Possibly this absence of the abovementioned organisms was due to the fact that the sample was taken in deeper water and with a large bottle that had a very narrow neck. The shape of the bottle was in itself enough to prevent obtaining an average and acceptable sample. On April 17, I9I6, another water sample from Lynnhaven arrived and was examined. This, however, showed no Navicula, but the absence on this occasion of the diatoms could be reasonably laid to the report that the greengills were clearing up in the bay and that no very green oysters could be found. Those which did have any pigment were very pale. On June 14, 1916, a similar water sample was examined, but this showed no Navicula ostrearia.

In an effort to ascertain whether the Navicula ostrearia inhabited the waters where the greengill had never been known to exist, and to further the theory that the blue 
diatom caused the greening, Narragansett Bay was studied in a general way with respect to its diatom growth. In samples taken in different parts of the bay and in sheltered locations along some of its inlets no diatoms that in any way answered the description of Navicula ostrearia were found. Further than that no classification of American diatoms that could be obtained gave any description of a Navicula of the characteristics that were typical of the organism found in the southern waters.

Following are the results of the examination of water samples from Narragansett Bay:

\begin{tabular}{|c|c|c|c|c|c|c|c|}
\hline Location. & $\begin{array}{l}\text { Specific } \\
\text { gravity. }\end{array}$ & $\begin{array}{c}\text { Tempera- } \\
\text { ture. }\end{array}$ & $\begin{array}{l}\text { Navicula } \\
\text { ostrearia } \\
\text { present. }\end{array}$ & Location. & $\begin{array}{l}\text { Specific } \\
\text { gravity. }\end{array}$ & $\begin{array}{l}\text { Tempera- } \\
\text { ture. }\end{array}$ & $\begin{array}{l}\text { Navicula } \\
\text { ostrearia } \\
\text { present. }\end{array}$ \\
\hline $\begin{array}{l}\text { Seekonk River ......... } \\
\text { Warwick Cove, } \\
\text { Shawomet Beach Cove. }\end{array}$ & & $\begin{array}{l}{ }^{\circ} \mathrm{C} . \\
4 \\
7 \\
6\end{array}$ & $\begin{array}{l}\text { No. } \\
\text { No. } \\
\text { No. }\end{array}$ & $\begin{array}{l}\text { Crescent Park Bridge. ......... } \\
\text { Dodge's oysterhouse........... }\end{array}$ & $\begin{array}{l}\text { I. OI4 } \\
\text { I. OII }\end{array}$ & $\begin{array}{c}{ }^{\circ} \mathrm{C} . \\
4 \\
3\end{array}$ & $\begin{array}{l}\text { No. } \\
\text { No. }\end{array}$ \\
\hline
\end{tabular}

The examination of the alimentary canal of 13 oysters with greengills which arrived some three or four days after shipment from Virginia showed in every case the presence of Navicula ostrearia frustules in the digestive tract. In 8 oysters the stomach contents were examined; in 3 the intestines were opened and their contents examined; while in the 2 others excrement was obtained from the rectum and in every case the presence of the sought-for frustules was determined.

\section{NAVICULA FUSIFORMIS var OSTREARIA.}

Lankester describes the Navicula fusiformis var. ostrearia, as a minute spindle-shaped diatom which measured about $\frac{1}{270}$ of an inch in length and $\frac{1}{7300}$ of an inch in breadth. It has two long and relatively large yellow-brown endochromes stretched out parallel to the surface of the organism, while at the tip ends, or scattered sometimes throughout the length of the organism, was a pale blue-colored protoplasm. The Navicula has a centrally located nucleus and several vacuoles located at intervals along its length.

The organism found in Virginia compares almost exactly with this description. Its measurement, obtained in this investigation, was about $\frac{1}{200}$ to $\frac{1}{300}$ of an inch in length, while in breadth at its broadest point it was found to be between $\frac{1}{2000}$ and $\frac{1}{2500}$ of an inch. In only this one particular are the observations at variance with Lankester's, but it is believed that either his drawings are not proportional to his measurements or there has been some typographical mistake in stating that the width of the organism at its greatest breadth is $\frac{1}{700}$ of an inch. Indeed, that measurement would mean that the organism was about 3 micra in diameter, which is absurdly small. The mistake is believed to be one of typography and not of scientific inaccuracy, since Lankester's drawings show the length and breadth relationship of his organisms to be exactly what was observed in the diatoms of the Virginia epidemic. The two endochromes, yellowish-green in color, were exactly analogous to those which Lankester deals with in his paper, while the blue protoplasm was also found in analogous locations, usually in the tip ends, but sometimes distributed throughout the entire length of the diatoms. Under changes in osmotic pressure the blue pigment, as well as the yellow-green endochromes, was affected. The blue pigment, which under ordinary conditions was held near the ends of the diatom, was freed suddenly from its location. It was diffused sometimes throughout the body of 
the organism and at other times it appeared in tiny droplets floating around inside the diatom. The green endochromes, sometimes one and sometimes both, often became twisted and curved out of their normal symmmetrical positions during osmotic changes and gave the diatoms an unbalanced appearance. The nucleus was always centrally located and under normal conditions was surrounded by a mass of transparent protoplasm. The vacuoles were located at intervals along the length of the organism. Observations on the size of the Naicula ostrearia were as follows: Length, I 31, 99, 93 , and I 28 micra; width, I2.8, 9.6, 9. I, and I I. 6 micra.

The frustules of the Variculu cotrariu found in the Chesapeake answer perfectly the descriptions given of the frustules of the Marennes Naicul.. ${ }^{a}$ They show a thick and distinct raphe with a valve difficult to distinguish. At a glance they appear smooth without transtcrse striæ, these being scarcely visible. The appearance of the Virginia Naricula ostraria compares exactly with that of the European diatom as set forth in Van Huerck's classification, "A Treatise on the Diatomaceæ."

\section{HISTOLOGY OF THE GREENGILL.}

In order to study the distribution of the green pigment in the gills, histological sections were cut and examined microscopically. The method followed was simply to kill the tissue in $\mathrm{HgCl}_{2}$, and then run it up through soft and hard parafin, cut, and finally stain with differential stains. Haidenhain's hematoxylin and eosin or orange $\mathrm{G}$ seemed to answer the purpose very well. It was found that the pigment was localized in relatively large, irregularly shaped cells which gave a granular green appearance. These cells did not react to any stain to give a coloring to them but remained green under all conditions. The pigment looked somewhat darker green after staining than it appeared in smears of the gill unstained, but this was probably due to a slight darkening that Haidenhain's had on the pigmented cells or because of the surrounding tissue which was stained rery darkly. The location of these cells was in the epithelial tissue of the gill filaments and along the epithelium which lined the interlamellar water space, especially in the vicinity of the interlamellar junctions. The appearance and location of these green cells exactly coincides with the description that Lankester gives of his "secretion" cells.

White gills of Narragansett Bay oysters were studied histologically by the same methods that were used in the greengill study. These showed exactly the same distribution of the large, irregular-shaped cells with granular protoplasm. These, however, were stained by orange $\mathrm{G}$ or cosin. The location and appearance of these cells were the same as of the pigmented cells in the greengills. This demonstrated that secretion cells were always present in and on the gills. Lankester said that these cells "furnish precisely the mechanism which we should expect to find in order that the blue pigment absorbed by the blood of the oyster from the contents of the alimentary canal, namely, from ingested Navicula ostrcaria, should be deposited at a particular spot on the animal's body. These secretion cells do not occur on other parts of the external surface of the oyster. They are limited to the surface of the branchix and to the adoral surface of the labial tentacles."

This selection and deposit of a pigment in a given tissue has been likened, as was formerly mentioned, to the deposition of the red color in the osseous tissue of pigs fed on madder. There is the same analogy found in experiments in which canaries are fed cayenne pepper, a diet which if continued will turn the wings a dark orange color.

a Dr. Albert Mann has examined some of the material and has confirmed the authors' identification of the Chesapeake diatom as Navicula ostreario. 
Another analogy to the selective power of the blood cells in green-gilled oysters is the selection by certain secreting organs in other animals. Palmer and Eccles have shown that cows fed on carotin will eliminate the pigment through the milk. More than that, they have proven that the carotin will be selected by fat cells and in this form will be received into the milk.

The kidney cells in all mammals also have a selecting power in separating out certain urine pigments which are later eliminated in the urine. The secretion cells in the oyster doubtless manufacture mucin under ordinary conditions, and probably in the exercise of this function dispose of the green pigment if the oyster again becomes colorless.

In a continuance of the microscopic study of the greengill, smears were made of the teased tissue of the pigmented gills. These showed the presence of the pigment in large irregularly shaped cells, the granular cytoplasm being distinctly green. These cells moved about in a typical amnboid manner, which led to the conclusion that possibly the secretion cells were nothing more than leucocytes. Smears of this gill tissue were compared with smears of white gills, and in each case the characteristic amœboid leucocytes appeared. Wright's bloodstain was then used on several smears, and in each case the green leucocytes stood out green against those of the white gill, which stained red with the eosin of the stain.

To prove that the Navicula ostrearia was the actual cause of the greening, an attempt was made to develop greengill in a normal white oyster taken from Narragansett Bay, where the greengill has never been known. The oyster was placed in aerated sea water which contained the Navicula ostrearia. After a wreek's time the oyster was examined and showed a pale green color in its gill tissue. 'To further prove that deposits of green pigment had occurred, smears were made of the gill tissue, and in each case they showed the characteristic green amœboid cells. Experiments to substantiate this study would have been continued, but the water samples subsequently obtained from Virginia were never very rich in diatom growth, and such efforts on the water samples received seemed futile. A control, however, was run on this greening experiment by placing an oyster from Narragansett Bay into aerated sea water from Virginia which contained no Navicula ostrearia. After a week's time this oyster was examined and showed no green coloration whatsoever. The secretion cells examined in a smear of the gills were normal in appearance.

The fact that green-gilled oysters depended on the presence of blue diatoms in considerable quantity, and the fact that the water samples from Virginia contained very few of the desired Navicula with which to carry on greening under controlled conditions, suggested the possibility of growing the Navicula in artificial culture media. Efforts, however, were all with negative results. Several culture media were tried at different temperatures, but none seemed to help in cultivating the organism. The solutions tried as media for the artificial cultivation of the diatoms were as follows:

I. Unfiltered sea water, sp. g. I.or4.

2. Filtered sea water, sp. g. I.or4.

3. Filtered sea water, sp. g. I.or4, I per cent lactose broth.

4. Filtered sea water, sp. g. I.or4, I per cent dextrose broth.

5. Filtered sea water, sp. g. I.or4, I per cent oyster broth.

6. Filtered sea water, sp. g. I.or4, I per cent ammonium nitrate.

7. Filtered sea water, sp. g. I.or4, I per cent ammonium chloride and sodium phosphate.

8. Filtered sea water, sp. g. I.or4, I per cent urea. 
6. Artificial sea water, $1,000 \mathrm{cc}$. of $\mathrm{H}_{2} \mathrm{O}, 25 \mathrm{gr}$. of $\mathrm{NaCl}$, I gr. of $\mathrm{MgSO}_{4}, 5 \mathrm{gr}$. of $\mathrm{CaCl}_{2}$, I gr. of $\mathrm{NaBr}$.

a I0. Artificial sea water, $1,000 \mathrm{cc}$. of $\mathrm{H}_{2} \mathrm{O}$, I gr. of $\mathrm{HNa}_{2} \mathrm{PO}_{4}$, I5 gr. of $\mathrm{NaCl}$, I gr. of $\mathrm{NaBr}, \mathrm{I}$ gr. of $\mathrm{CaCl}_{2}$.

Ix. Artificial sea water, same as No. 9, with straw and moss added.

12. Artificial sea water, same as No. IO, with straw and moss added.

One set of these solutions was kept at room temperature and another at approximately $26^{\circ} \mathrm{C}$.

The solutions which contained the dextrose, lactose, and oyster broths were sterilized to prevent too flourishing bacterial growth. The broths here mentioned were those used in bacteriological work.

These solutions were then inoculated with a considerable quantity of diatoms of different species, but in no case did any reproduce, though some lived at least three days in the new environment.

From observations of the water samples from Virginia it was noted that continual slight motion of the water sample and atration tended toward prolonged life of the diatoms.

Further experiments on the isolation and artificial cultivation of these and other diatoms are projected.

\section{THE CHEMISTRY OF GREEN-GILLED OYSTERS.}

The only chemical work that had been done on the green pigment of Marennes oysters at the time of this investigation was summed up in Lankester's work. That work shows that the pigment was insoluble in water, dilute acids, dilute alkalies, alcohol, ether, glycerine, and benzol, either hot or cold, and that the coloration was not due to the presence of copper or any other metallic element. It shows further that strong acids or alkalies dissolved but at the same time destroyed the pigment.

Lankester examined spectroscopically green-gilled tissue with the use of a powerful ray of light. He found, however, that this demonstrated no isolated absorption bands in the spectrum. He also examined in like manner a mass of Navicula ostrearia, but detected no absorption bands in the spectrum.

The first investigations in this problem carried on in respect to the chemistry of the greengills was to ascertain whether or not there was any copper present in the gills. Four grams of desiccated greengill were digested in sulphuric acid and potassium nitrate. After compiete digestion, and after making the solution ammoniacal, only the faintest trace of yellowish-green color could be detected. This test showed the absence of all but the faintest trace of copper, which has been found to be present in all oysters. This experiment was repeated with the same result. Lankester said in this connection: "Whilst there are so many considerations which explain the origin of the notion that copper may be responsible for the green color of the 'huitres de Maremes,' although that metal has nothing to do with it, it is extremely remarkable as a coincidence that of late years it should have been established that copper in minute quantitics is a normal constituent of the blood of molluscs." Further evidence that the greengill contained no abnormal amount of copper was seen in the fact that the people of the vicinity who ate the oysters raw in considerable quantities noticed no abnormal taste. Surcly had the green color been due to a copper compound, there would have been enough present in specimens so intensely pigmented to have given the so-called coppery taste that many observers claim is characteristic of oysters containing excessive copper.

a 9 and zo contained also a considerable quantity of dead diatom material. 
The solubilities of the pigment were then studied, using the green-gilled tissue as freshly taken from the living oyster and the tissue after it had been thoroughly dehydrated. The gills of several oysters extracted in alcohol, 95 or 1oo per cent, gave a slight yellowish-green coloration to the extract. A carbon disulphide extract of greengills yielded also a yellow-colored solution. But when either one followed the other the second was always somewhat paler. The gills, however, always remained green after such extraction, showing that the green pigment was insoluble in carbon disulphide or alcohol. White oysters yielded the same results. So it appears that these extractions were merely dissolving a pigment common to any oyster gill, probably a lipochrome. A yellow carbon disulphide extract was evaporated down and left a yellow residue that was insoluble in water. This residue was mixed with oil and subjected to the Crampton-Simon test for the detection of carotin. The result was negative. Chloroform and ether were also turned a yellow color when used to extract the greengill, but as in the case of other solvents, the extract did not differ from that obtained from normal oysters.

In dehydrating the green-gilled tissue, the following reagents were used in the order mentioned: Alcohol, ether, and carbon tetrachloride. This method always left the carbon tetrachloride slightly yellow colored and gave a dark green residue of dried gill tissue. This dehydrated tissue was then ground and used in solubility tests that followed. The solvents in different strengths of alkali and acid were used, with the following results:

ALKALI.

$0 . I, 0.2,0.3,0.4,0.6, I .2, I .5,3$, and 6 per cent potassium hydroxide; no pigment dissolved. Material from greengill swelled up into a flocculent gelatinous mass with unchanged color. The supernatant fluid gave an opalescent appearance, but there was no solution of the pigment.

I2, 30, and 60 per cent potassium hydroxide; decomposed green-gilled material, leaving a greenishbrown residue.

The same results were detected when the solutions were kept at room temperature during 24 hours, or when boiling solutions were used during short periods.

ACID.

$0.01,0.05,0.1,0.2,0.4,0.6,0.8, I .2,2,2.5,3$, and 3.5 per cent hydrochloric acid; no action noticeable.

4,7 , and 5 per cent hydrochloric acid; slight yellowish-green coloration, but green-gilled material remains unchanged.

I8 per cent hydrochloric acid; disintegrated tissue and turned black.

In the last four strengths of acid recorded, probably disintegration was taking place, while actual dissolving of the original pigment did not occur.

The above results on acids were detected when the solutions were either hot or cold, or when the pigment was allowed to remain in the solution for a period of 24 hours. The same results were observed when alkalies were used. Hot or cold water did not dissolve the green pigment.

After the pigment had been shown to be insoluble in the common solvents, experiments were undertaken to ascertain if there was any chemical combination of the pigment with a protein or fat molecule. In the investigation on this point, green-gilled tissue was subjected to a gastric digestion first, by putting several gills into a 0.2 per cent acid solution of pepsin and allowing the digestion to go on for three days at $37^{\circ} \mathrm{C}$. On the third day the digestion was examined, and a small amount of green material was 
found as a residue, while the liquid had a greenish opalescense. This liquid was filtered off, and the green substance was subjected to a number of different solvents, both hot and cold, but the pigment still remained insoluble in all reagents used.

The solvents tried after gastric digestion were: Alcohol, water, 2 per cent sodium chloride solution, ether, chloroform, carbon disulphide, toluene, carbon tetrachloride, acetone, ethyl acetate, 0.5 per cent sodium carbonate, I2 per cent sodium hydroxide, 0.2 per cent hydrochloric acid, and 12 per cent hydrochloric acid.

The green residue of this digestion was then placed in a pancreatic digestion with the addition of a number of other green-gilled tissues. This digestion was carried out by adding a small amount of tested pancreatin to a 0.5 per cent sodium carbonate solution, and allowing the green material to remain in this for three or four days at $37^{\circ} \mathrm{C}$. The result in this case was very similar to the gastric digestion, a green residue remaining with a greenish-opalescent supernatant solution. After filtering and washing the residue with distilled water, the green pigment was still found to be insoluble in the solvents used, whether at boiling or room temperature.

The following solvents were used after the pancreatic digestion: Alcohol, water, sodium chloride, 2 per cent; ether; chloroform; carbon tetrachloride; carbon disulphide; toluene; acetone; ethyl acetate; sesame oil; olive oil; glycerol; cottonseed oil; linseed oil; paraffin oil; gasoline; acetic acid, o.5 per cent; lactic acid, I per cent; lactic acid, 0.5 per cent; salicylic acid; and sodium carbonate, 0.5 per cent.

Putrefaction destroyed the pigment slowly. A solution containing sereral greengills allowed to putrefy gave a dark green color to the liquid. Green oysters allowed to die and putrefy showed that the gills turned black, or a very dark green, and finally were thoroughly destroyed, leaving a black mass of foul-smelling organic matter.

The green residue of a pancreatic digestion was then subjected to saponification in a I per cent alcoholic sodium-hydroxide solution. This solution was made by distilling absolute alcohol over potash until a distillate was collected that was free from all impurities that might give a yellow color with alkalies. This distillate was then made into a $x$ per cent solution of alcoholic sodium hydroxide, using chemically pure sodium hydroxide. The green pigment material was thereupon allowed to saponify by boiling two hours, after which the solution was filtered. The saponification yielded a yellowcolored solution. This was neutralized with hydrocholoric acid with the resulting precipitation of sodium chloride. This solution was then evaporated down to about to cc., filtered, and studied spectroscopically.

As a control on this experiment, a like quantity of normal gills was subjected to a similar pancreatic digestion. The solid matter that remained after a three days' digestion was then saponified for two hours at boiling temperature in a I per cent alcoholic sodium-hydroxide solution prepared as above. The resulting solution was very nearly colorless, and after neutralizing, filtering, and evaporating, only a suggestion of yellow color could be detected.

The spectroscopic examination of the green-gilled saponification showed an absorption band covering the violet end of the spectrum. Examination of the normal gill material obtained from saponification showed no shadows whatsoever in the spectrum.

To establish the fact that the green coloration of the gills in Virginia oysters was not due to the presence of a bacterial pigment, the pigmented gills were subjected to bacteriological examination. 
Small pieces of the pigmented gill were placed in sterile water and shaken up thoroughly and then plated out on nutrient agar in Petri dishes, with the usual bacteriological technique. No color-producing organisms were obtained in three trials. Abundant colonies of white bacteria were observed.

\section{CONCLUSION.}

The investigations seem to warrant the following conclusions:

I. The Chesapeake green-gilled oyster is the same as the so-called Marennes oyster.

This conclusion is reached since the Virginia oyster corresponds exactly to the descriptions of the Marennes oyster in general appearance and in microscopic examination. The greengills and palps of our southern oyster coincide precisely with the descriptions and drawings of the French oysters, and the method of distribution by secretion cells and the location of the pigment in definite tissues of the gills, as explained by Lankester, is the same as has been found in these observations of the Lymnhaven oyster. A diatom answering the same description as the Navicula ostrearia, recognized as the cause of the greening of Marennes oysters, has been identified wherever green oysters were found in the Chesapeake. The frustules of the diatom have also been obtained from the intestines of the green oysters in this observation exactly as Lankester noted in his study of the Marennes oyster. Again, this investigation agrees thoroughly with the conclusions of several European workers that the pigmentation of the gill can occur by allowing the oyster to remain in sea water in which there are Navicula ostrearia, but that there is no coloration if the Navicula are absent.

The observations in this investigation on the chemistry of the pigment of Chesapeake green oysters are exactly the same as those made on the Marennes greengills by Iankester. The extreme insolubility of the pigment noted by this investigator as characteristic of the European oyster is in direct harmony with the studies recorded in this investigation.

2. No evidence that the coloration of the gills of Chesapeake green oysters was due to bacteria was found in the investigation.

3. The pigment found in the greengills of Chesapeake Bay oysters yields a saponification product that shows an absorption band covering the violet of the spectrum. 
BOUBÉS, CharLes.

\section{BIBLIOGRAPHY.}

I909. L'ostreiculture à Arcachon. 333 p., illus., map. Bordeaux.

CALVERT, LOUTS.

I910. Contribution a l'etude du verdissement des huitres. (Rapport presente au Congres des Sables-d'Olonne.) Ve Congres national des peches maritimes. Memoires et Comptes rendus des seances. T. I., p. 673 $\rightarrow$ II. Orleans.

HERDMAN, WILLIAM ABBotT.

1898. Life conditions of the oyster: Normal and abnormal. Third and final report of the committee ... on the elucidation of the life conditions of the oyster under normal and abnormal environment, including the effect of sewage matter and pathogenic organisms. (Drawn up by Herdman, Boyce, and Kohn.) Report of the British association for the advancement of science for I898. Section D., II p. London.

1899. Oysters and disease. An account of certain observations upon the normal and pathological histology and bacteriology of the oyster and other shellfish. (Lancashire sea-fisheries memoir no. 1.), 60 p., vir pl., partly col. London.

\section{KELLOGG, JAMES L.}

1910. Shell-fish industries. 36 I p., 67 text fig., 33 pl. New York.

LANKESTER, EDWIN RAY.

I886. On green oysters. Quarterly journal of microscopical science, vol. xxvi, n. s., p. 7I-94, pl. vII. London.

LEWIS, F. W.

186I. Notes on new and rarer species of Diatomaceæ of the United States seaboard: Proceedings, Academy of Natural Sciences of Philadelphia, p. 6I 7 I. Philadelphia.

MANN, ALBERT.

1894. List of Diatomaceæ from a deep-sea dredging in the Atlantic Ocean off Delaware Bay, by the United States Fish Commission steamer Albatross. Proceedings United States National Museum, vol. Xv1, p. 303-312. Washington.

MurRay, GEORGE.

I8g5. On the reproduction of some marine diatoms. Royal society of Edinburgh. Proceedings, 1895-1897. vol. Xxi, p. 207-218, 3 col. pl. Edinburgh.

SCHRÖTER, C.

I8g6. Die Schwebeflora unserer Seen. (Das Phytoplankton). 59 p., I pl. Zürich.

Sulirvan, W. K.

1870. Report on the composition of the soils of oyster grounds; and on qualities which exert most influence on oyster cultivation. Appendix H. Report of the commission appointed to inquire into the methods of oyster culture in the United Kingdom and France, with a view to the introduction of improved methods of cultivation of oysters in Ireland, p. I66-176. Dublin.

VAN HEURCK, H.

1909. Diatomees. Resultats du voyage du S. Y. Belgica en 1897-1899. Rapports scientifiques ... Botanique. $128 \mathrm{p}$., XIIr pl. Anvers.

WOLLE, Francis.

1894. Diatomaceæ of North America. 47 p., cxin pl. Bethlehem. 

Hollinger Corp. pH 8.5 